\title{
The Effect Of Think Pair on Students's Writing Skill Through Padlet For Tenth Grade At SMA Muhammadiyah IX Brondong
}

\author{
Mujahidatul Muslimah Z.H. \\ SMA Muhammadiyah IX Brondong, Lamongan, Indonesia \\ Mujahidatulmuslimah19@gmail.com \\ Khoirul Anwar \\ Universitas Muhammadiyah Gresik, Indonesia \\ Khoirulanwar@umg.ac.id \\ Candra Hadi Asmara \\ Universitas Muhammadiyah Gresik,Indonesia \\ Candrafkip@umg.ac.id
}

Received: Agust 10, 2020

Accepted: August 17, 2020

Published: September 9,2020

DOI: http://dx.doi.org/10.30587/jetlal.v4i2.2276

\begin{abstract}
Good writing is important aspect in teaching writing subject. But, the researcher find on the students some problems that they faced in their writing which are in generating the ideas, orginizing and vocabulary. Besides, the teacher also has problems in applying the appropriate strategy and media in teaching writing. Based on the previous studies, Think Pair Share strategy gave the positive effect for the students. This study was to examine the significant effect of Think Pair Share on Student's Writing Skill through Padlet for $X^{\text {th }}$ Grade at SMA Muhammadiyah 9 Brondong. And the researcher uses quasi Experimental design. The researcher choose Tenth grade at SMA Muhammadiyah 9 Brondong which totally consisted of 56 students. The researcher used cluster sampling because the school has been detemined the classification of the students. It was included 28 students of X IPA 1 as the Experimental Group and 28 students of X IPA 2 as the Control Group. The data was gathered by utilizing tests; pre-test and post-test about composing illustrative content. In the wake of getting the information, the specialist broke down the information utilizing SPSS 16.0 and utilized Independent Sample T-test. The examination finding indicated that there was a noteworthy contrast between test bunch that were educated by utilizing Think Pair Share through Padlet and control bunch that were instructed by utilizing Think Pair Share through Pictures.. It was Therefore, the researcher suggest to the English teacher for implementing of Think Pair Share strategy through Padlet as an altenative strategy in English teaching learning process and hopes to use Think Pair Share strategy through Padlet in other skills and levels to make different with the previous study.proven by the result of sig.(2tailed) is .000 . The sig. (2tailed) is lower than $0.05(0.00<0.05)$ so, null hypothesis $(\mathrm{H} 0)$ can be rejected. The researcher concluded that Think Pair Share Strategy gave positive effect on student's writing skill. The students were motivated and independent in learning writing especially in eneratig the ideas, organizing the ideas, and vocabulary. This research contributes by forming new think pair share steps which are associated with the use of technology that can help students much better in discussing in a learning that is the padlet.
\end{abstract}

Keywords : Writing Descriptive Text, Think Pair Share (TPS), Padlet

\section{Introduction}

Up to now, the problem in writing at English class is still a matter that is still widely discussed. There are still many researchers who find out the common causes of problem on writing in English. Writing learning so far only leads to individual aspects rather than interpersonal aspects. Where there are various aspects of the problem in it, namely the linguistic aspects and cognitive aspects. The problem a rises because 
writing learning is still only individual rather than interpersonal. It is proven by the existence of several previous studies, in the research of Dwi Pratiwi Christian (2012) using descriptive method explaining that the problems faced by students are linguistic and cognitive aspects where writing learning is done individually not interpersonally. In the research conducted by Dr. Ibrahim Mohamed Alfaki (2015) also found cognitive problems and linguistic problems. The class studied also uses individual learning giving rise to linguistic problems and cognitive problems.

The first problem of writing skill that faced by the students in generating the ideas. As indicated by raimes (1983) there are as yet numerous understudies who think that its hard to communicate their considerations and thoughts, words, sentences and passages in a decent type of composing. Raimes (1983: 13) additionally expresses that "when understudies think that its hard to compose English, they not just think that its hard to utilize words and legitimate sentence structure however they likewise think that its hard to communicate thoughts utilizing their own new dialect. The second problem in writing is organizing. According to zamel (1983: 22) one of the biggest problems that causes difficulties for students in writing is being unable to write cohesively, even though cohesive matters play an important role in writing. According to Pincas (1982) also states that the difficulty for students in learning to write English is the inability of students to write cohesive paragraphs. The third problem of writing is Vocabulary. According to Jordan (1997), in writing there are several things that make it difficult and confusing, namely a way in the process of putting words in written form with the same structure in outlines and the right vocabulary. According to Shejbalová (2006) and Lado (1955) the difficulties faced by students in writing English are related to vocabulary, where most students cannot remember important words used, unable to use the right words. Alkhairy (2013) also stated that one of the main problems causing difficulties in writing English is the lack of vocabulary.

From the problems that have been mentioned and the biggest problems in the classroom, namely learning that is only focused on individuals is not personal, a strategy that can accommodate the interests of two interrelated things is needed, namely cognitive and interpersonal relationships in it. So the researcher uses a strategy that is cooperative learning. According to Johnson and Holubec (1993) cooperative learning is a strategy in learning that helps students maximize the learning process with each other when they discuss. Slavin (1996) also claims that with cooperative learning, learning in the classroom has the purpose of being able to discuss each other. And one of the strategies part of cooperative learning that is most popular and suitable for solving this problem is to use Think Pair Share. Think Pair Share is kinds from Cooperative Learning type designed to influence student interaction in learning. In Think Pair Share (TPS) requires that one student with another student can work together in their groups, in one group usually consists of 2-4 students (Ibrahim et al: 2000). Based on Lyman (1981) quoted in Lie (2002:57), states that there are three steps in the think pair share technique, namely think, pair, share.

As reviewed by the previous researchers above, most of them examined the effectiveness of Think Pair Share in many areas. One of previous study in research of Muhammad Ariansyah, et al,. Explained that Think Pair Share is effective strategy that used to improve student's writing skill but will be more effective if the next researcher used this strategy combined with attractive media for teaching to generate their ideas easier. So far, the researcher does not find any research which attempts to examine the efficacy of Think Pair Share strategy using media. One of the media that used in this study is E-learning, it is Padlet. Wood (2016) said that Padlet is one of attractive online media because in using the padlet, users can add images, documents, text, links and videos to the walls of their padlets. In the use of padlets, padlets provide benefits for teachers in monitoring students in interacting with each other and managing their class performance.

From the problem and explanation above, the researcher decides to carry out the study entitled "The Effect of Think Pair Share on Student's Writing Skill through Padlet for $\mathrm{X}^{\text {th }}$ Grade at SMA Muhammadiyah 9 Brondong."

\section{a. Writing Descriptive Text}

Based on Harris (1993:10), writing is the process that needs much time to procedure our vocabularies. We have to think what we want to write in the piece of paper. Brown (2001) stated that writing is how the writers give information and message to make the readers understand what the writer's opinion in their writing. based on Oshima and Hogue (1999) quoted in Rosnani Sahadin,et al (2017) stated that there are five stages in writing process, they are pre writing, planning, writing or drafting, revising the draft, and final editing. based on Bachyani (Rachmayanti;2013) stated that in teaching writing there are some rules. They are knowing the student's need, supporting to the students motivate to express their idea, showing the understudies sentence structure and vocabulary comprehensively in the composing task, and then the teacher must be trying to accept the ideas and composition of students. 
As indicated by Tompkins (1994) and Stanley (1988), descriptive text is as painting pictures with words. By reading a descriptive text, readers feel that they see the description just like they see pictures. Descriptive text has the purpose to describe an object or a person that the writer is interested in.

\section{b. Think Pair Share}

Think Pair Share is a cooperative learning discussion. It is simple strategy but very useful which developed by Frank Lyman of the University of Maryland. Meanwhile, Jollife (2007:44) argued that cooperative learning structures create a situation in which the students can discuss with other students in solving problems. According to Lie, 2002:57 (Lyman;1981) argued that there are three steps of cooperative structure in Think Pair Share. They are Think, Pair, and Share. Kagan (1994) stated TPS is a cooperative learning strategy that can promote and support higher level thinking. Mc Candlish (2012:2) mentioned that Think Pair Share as a cooperative strategy has three parts on the process. First, the students think about an issue or a question, second is they must to talk their thought with a partner on discussion, third is the student's partner share their result of discussion to whole classroom. Based on Kenney (2005) stated the benefits of Think Pair Share are that students have the right time to think so that students' responses become more active besides students also have the opportunity to think critically when discussing with each other. Moreover the students will be involved actively thinking. Beside that, he also said that with Think Pair Share, the students feel more relaxed and easier to discuss with their friends. The used of Think Pair Share in teaching writing is the activity that interesting in english learning. Think Pair Share is one of cooperative learning where it is good strategy that used as interactive and active process in teaching writing.

\section{c. Padlet}

Nitesh Goel is the founder and CEO of Padlet. Padlet is an online notice board and it tends to be utilized to welcome members to make and to team up by sharing their thoughts, just as including pictures, recordings, connections, and reports in the posts. A padlet is a web-based online wall feature where we can post ideas or anything via a virtual post (Shield, 2014). This media provides good use to students in learning even without having to have an account first. With padlets,

users can create walls like whatever they want and they can also invite or invite

anyone to join their walls, besides also in the padlet, we can adjust and adjust the

privacy of our walls as we want (Fiester\& Green, 2016; Miller, 2016). Based on Fuchs (2014), Padlet has many benefits in learning in the class. When the teacher gives a question to the student, the teacher does not have to give it orally, the teacher can post anything on the wall of the padlet. Students can respond to questions from the teacher easily through the wall of the padlet, besides that students can read answers from other friends and also can evaluate the responses of other friends, so that they can interact with each other. The Procedure of Using Padlet, they are you can log in with google or facebook, Or when you want to create a new padlet account, click o "Sign up", And when you have entered in padlet home page, then if you want create a new wall, so click on "Create New Padlet", welcome your first padlet wall, Then you can designing anything what do you want.

\section{Research Method}

Experimental research is the design of this study. Miller (1984:4) explained that experimental design is a process to collect the research data to know the effect of variable and the other variable. It is purpose is to examine the theory, so the aim of this study is to examine the effect of Think Pair Share through Padlet in writing descriptive text. This study uses quasi experiment use to predict the cause and effect of the relationship between dependent and independent variable. The researcher uses quasi experiment because the school does not allow the researcher to do randomization and do true experiment at SMA Muhammadiyah 9 Brondong. Population is all data that is targeted in the specified time and scope (Margono, 2005: 118). The population of this research is the students of SMA Muhammadiyah 9 Brondong who are in tenth grade. There are two classes with 56 students as the total of subjects. They are divided into two groups, one is experimental group and another is control group. In this research the technique is cluster sampling. Ary (1990), argued that cluster sampling is choosing a group already together not an individual. The researcheruses technique of cluster sampling because the school has been determining the classification of the class. Here, X IPA-1 will be as experimental group which consist of 28 students and X IPA- 2 will be as the control group which consist of 28 students. The instrument of this research are pre-test and post-test. the rubric scoring for pre-test and post-test to assess the students writing descriptive text based on Brown (2007). After collecting the data, the researcher will analyze the data. The assumption for independent t-test where : (1) Independence : 
observations within each sample must be independent, (2) Normal Distribution : the two population must be normally distributed. This study is included in parametric research which divides into two kinds of the data; ration and interval. The data of this study is ratio because zero has value or absolute zero. Ratio data is defining homogeny and normal distribution. The last, (3) Homogenity of Variance : the two populations must have equal variance.

\section{a. Result}

The result of the students' score was analyze by three people. The first corrector was the researcher herself, the second corrector was an english teacher of tenth grade and the third corrector was an english teacher and also as the headmaster of SMA Muhammadiyah 09 Brondong. The pre-test score and post-test score of experimental group and control group were presented in the appendix. The mean of the pre-test of the experimental group was 56.7857 and the mean of the pre-test of the control group was 58.7857. . The result showed of Kolmogorov Smirnov Sample Test for Equality of variences showed that the sig.is $0.200>0.05$, so two populations of varience were normal. And $F=0,006$ and the sig. $=0,940$ which means that there was no different varience between experimental group and control group because the sig.was higher than the level of the significance $0,940>0,05$. It means that two populations of varience were homogenous or equal. . From the post analysis, the mean of the post-test of the experimental group was 78.8929 and control group was 69.6786. Then the researcher analyzed the hypothesis testing and the result showed that the value of sig.(2tailed) was 0.00 in critical value for $5 \%$ level.

\section{b. Discussion}

With the implementation of traditional think pair share, it is used in the current era where it is full of technology that all children are familiar with technology so that they have more disadvantages than strengths. So that researchers review some steps of think pair share from one study to another research. And even to this day, none of the researchers has combined think pair share with technology. Because it is possible that the steps of think pair share will always develop, the researcher offers with the use of Padlet, why the padlet? because this online media is one that is booming where the appearance of the padlet is similar to facebook. Other than, we know that Padlet is one of made which uses technology to the learning process, and helps the learning process based on the scientific approach that is used in K13 curriculum. In Think Pair Share strategy through Padlet we try to apply the process of teaching learning writing in the tenth grade at SMA Muhammadiyah 9 Brondong. In addition, it is impossible for the traditional think pair share to be combined with a padlet in an English language learning especially in English writing without any research. So that research needs to be held first. So, this research raises new steps from existing steps by combining online media, namely padlet. Now these are the steps that I have come up with as a contribution to my research.

1. Think

The researcher divide the students into pairs

$>$ The students are given directions for Think Pair Share through the Padlet on the LCD Projector.

$>$ The researcher gave the task on Padlet and asked the students to do it.

$>$ The students are given time several minutes to do the task individually

In this stage, think pair share with padlet can more manage time than without padlet because when the teacher post anything, all of the students can see it together. So the teacher not explain or give the task one by one manually.

2. Pair

The researcher asks the students to discuss with her / his partner

$>$ The students determine the best answer or the conclusion for the answer of the task

$>$ Each group posts their answer on the Padlet

In this stage the students more practical to do the task because the students can discuss with their partner then post their answer on padlet

3. Share

$>$ The students were asked to share their anwer (each group) on the Padlet

$>$ The students give corrections to each other by commenting on their friends' posts on the Padlet

In this stage, Padlet is very useful because with padlet the discuss on this stage is good manage. In this stage, the students can share and give correction each other together so it is more good manage the time 
than without padlet. Because in control class, most of students, some cannot share their answers to whole classroom because time is up so they cannot finish the discussion and give feedback each other maximally.

\section{Conclusion}

Based on the result of the study about Think Pair Share strategy through Padlet in Writing Descriptive Text, the researcher agrees that the theory. it can be applied for narrative, recount, report, and descriptive text. Of course this research contributes by forming new think pair share steps which are associated with the use of technology that can help students much better in discussing in a learning that is the padlet. The implementation of Think Pair Share strategy through Padlet can make the students easy to develop their idea into a paragraph with good cohesiveness and coherence. Additionally, Think Pair Share strategy through Padlet make easy the students to improving their vocabulary. This strategy also help the students to focus on the topic.

This Think Pair Share must always be search for adjustment, changes and adapted to needs of learners at all times because the needs of these learners are always changing related to technology needs.

\section{References}

Anwar, Choiril, Kurniawan Yudhi Nugroho \& Idha Nurhamidah. 2019.

Students' Perception at the Use of Padlet in Linguistics Class. Journal of Linguistic Literature and Culture, Volume 01, Number 01, May 2019.

Ariansyah, Muhammad, Fadly Azhar \& Masyhur. 2016. The Use of Think-Pair- Share Technique to Improve the Writing Ability of the Students of SMA Negeri 03 Pekanbaru in Recount Text. Pekanbaru: University of Riau.

Astheri, Marchelina Lucy, Dahlan Rais \& Teguh Sarosa. 2013. Improving Students' Writing Skill by Using Think Pair Share (TPS). English in Education.

British Course. 2017. Descriptive Text (Complete Explanation):

http://britishcourse.com

British Course. 2017. 20 contoh Descriptive Text terbaik: http://britishcourse.com.

Cara Mudah Belajar Bahasa Inggris. 2014. Contoh Descriptive Text Tentang Kuta Beach dan Artinya: https://www.caramudahbelajarbahasainggris.net.

ContohText. 2018. Contoh Descriptive Text about Prambanan Temple Singkat dan Terjemahannya: https://www.contohtext.com.

Fauziyati, Diyah Reni \& Wiwiek Istianah. 2013. The Effect of Using Think-Pair- Share Technique on the Eighth Grade Students' Reading Comprehension Achievement at SMPN 3 Bangsalsari Jember. Jember: UNEJ.

GudangPelajaran. 2017. 23+ Contoh Descriptive Text Lengkap Beserta Strukturnya Pengertian, Ciri-Ciri dan Tujuan: https://gudangpelajaran.com.

Haris, Munirah Melor Md. Yunus \& Jamaludin Hj Badusah. 2017. The Effectiveness of Using Padlet in Esl Classroom. International Journal of Advanced Research.

Hidayati, Ida Ubaidah. 2017. The Use of Think, Pair, Share Learning Method to Improve Vocabulary Mastery of the Second Class Students of Muhammadiyah Vocational High School, Salatiga in Academic Year 2011/2012. Salatiga: UNNES. 
Khalifa, Rasha Mohammed. 2012. The Effectiveness of Using Think- Pair - Share Strategy on Developing Eleventh Graders' Writing Skills in Rafah Governmental Schools. Rafah: Al-Azhar University.

Kurniasih, Fajar. 2017. The Implementation of Think-Pair-Share` (TPS) Technique in Teaching Reading Comprehension at SMAM 14 Bandarlampung. Bandarlampung: University of Lampung.

Lukman, Intaniya Fathanty. 2016. The Effectiveness of Think-Pair-Share Technique toward Students Ability in Writing Descriptive Text at the Eighth Grade Students of SMP Negeri 3 Sinjai. Makassar: Alauddin State Islamic University of Makassar.

Materi Belajar. 2018. 6 Contoh Descriptive Text Tentang Tourism Place (Tempat Wisata): http://materi4belajar.blogspot.com

Oktaviani, Anisa. 2017. The Use of Think Pair Share Technique to Improve Students' Writing Recount Text at the First Grade Students of SMAN 14 Bandar Lampung. Bandar Lampung: University of Lampung.

Sahardin, Rosnani, Cut Salwa Hanum \& Sofyan A.Gani. 2017. Using Think-Pair- Share for Writing Descriptive Texts. Banda Aceh: University of Syiah Kuala.

Saliputra, Ade Neni. 2013. Improving Report Text Writing through Think-Pair- Share. Pontianak: Tanjungpura University.

Sugiarto, Dino \& Puji Sumarsono.2014. The Implementation of Think-Pair-Share Model to Improve Students' Ability in Reading Narrative Texts.

Ampelgading: University of Muhammadiyah Malang.

Syahputra, Adly \& Elia Masa Ginting. 2015. Improving Students' Achievement in Writing Descriptive Text through Think Pair Share. Rantauprapat, North sumatra: UNIMED.

Wordcliff. 2019. Contoh Descriptive Text Bahasa Inggris Singkat Tentang Monas: http://www.wordcliff.com.

Yulianingsih, Lia. 2017. The Use of Think Pair and Share Technique in Teaching Reading to the Seventh Grade of Senior High School. Cirebon: University of Swadaya Gunung Jati. 